from Australia carrying $b l a_{\mathrm{NDM}-1}$. Diagn Microbiol Infect Dis. 2014; 78:93-7. http://dx.doi.org/10.1016/j.diagmicrobio.2013.08.001

5. Li JJ, Lee CS, Sheng JF, Doi Y. Complete sequence of a conjugative IncN plasmid harboring $b l a_{\mathrm{KPC}-2}, b l a_{\mathrm{SHV}-12}$, and qnrSl from an Escherichia coli sequence type 648 strain. Antimicrob Agents Chemother. 2014;58:6974-7. http://dx.doi.org/10.1128/ AAC.03632-14

6. Villa L, Garcia-Fernandez A, Fortini D, Carattoli A. Replicon sequence typing of IncF plasmids carrying virulence and resistance determinants. J Antimicrob Chemother. 2010;65:2518-29. http://dx.doi.org/10.1093/jac/dkq347

7. Huang TW, Wang JT, Lauderdale TL, Liao TL, Lai JF, Tan MC, et al. Complete sequences of two plasmids in a $b l a_{\mathrm{NDM}-1}$-positive Klebsiella oxytoca isolate from Taiwan. Antimicrob Agents Chemother. 2013;57:4072-6. http://dx.doi.org/10.1128/ AAC.02266-12

8. Qu H, Wang X, Ni Y, Liu J, Tan R, Huang J, et al. NDM-1-producing Enterobacteriaceae in a teaching hospital in Shanghai, China: IncX3-type plasmids may contribute to the dissemination of $b l a_{\mathrm{NDM}-1}$. Int J Infect Dis. 2015;34:8-13. http://dx.doi.org/10.1016/j.ijid.2015.02.020

9. Tijet N, Richardson D, MacMullin G, Patel SN, Melano RG. Characterization of multiple NDM-1-producing Enterobacteriaceae isolated from the same patient. Antimicrob Agents Chemother. 2015;59:3648-51. http://dx.doi.org/10.1128/AAC.04862-14

10. Shahcheraghi F, Nobari S, Rahmati Ghezelgeh F, Nasiri S, Owlia P, Nikbin VS, et al. First report of New Delhi metallo- $\beta$-lactamase-1producing Klebsiella pneumoniae in Iran. Microb Drug Resist. 2013;19:30-6. http://dx.doi.org/10.1089/mdr.2012.0078

Address for correspondence: Yohei Doi, Division of Infectious Diseases, University of Pittsburgh School of Medicine, S829 Scaife Hall, 3550

Terrace St, Pittsburgh, PA 15261, USA; email: yod4@pitt.edu

\section{Ritual Slaughter as Overlooked Risk Factor for Brucellosis}

\section{Inbal Fuchs, Lidia Osyntsov, Yael Refaely, Pnina Ciobotaro, Oren Zimhony}

Author affiliations: Clalit Health Services, Beer Sheva, Israel

(I. Fuchs); Ben-Gurion University of the Negev, Beer Sheva

(I. Fuchs); Soroka University Medical Center, Beer Sheva

(L. Osyntsov, Y. Refaely); Kaplan Medical Center, Rehovot, Israel (P. Ciobotaro, O. Zimhony)

DOI: http://dx.doi.org/10.3201/eid2204.151192

To the Editor: The current rates of animal and human brucellosis in southern Israel are unacceptably high (1). Unsupervised livestock rearing, smuggling of herds, and the dissolution of Israel's "test, slaughter, and compensate" program for small ruminants in 1997 have generated a large, uncontrolled animal reservoir in the region. The Bedouin Arab inhabitants who live in close proximity to herds and consume unpasteurized dairy products are disproportionately affected. Outbreaks from parts of Israel that were previously free of brucellosis are reported with increasing frequency. Moreover, 2 decades after supposed elimination of bovine brucellosis, a cattle herd adjacent to Bedouin grazing areas was found to be highly infected with Brucella melitensis (2).

We report 5 cases of severe brucellosis in patients from a community whose members typically do not raise herds and do not consume unpasteurized dairy products. The patients were Ethiopian-born Jews who exhibited fever and either respiratory signs or radiologic evidence of new pulmonary findings (Table). The true nature of the infection only became evident when $B$. melitensis was identified from blood cultures. Directed questioning revealed that all patients participated in ceremonial slaughter of sheep that were purchased from Bedouin owners in southern Israel.

The diagnostic pitfalls encountered by the medical staff are exemplified in the case of patient 1 (Table). In May 2014, this 68-year-old man was admitted to a hospital in southern Israel, with a 14-day history of fever, cough, and night sweats. His medical history was notable for asthma and previously treated pulmonary tuberculosis (TB). Computed tomography scan of his chest showed a new $1.5-\mathrm{cm}^{2}$ apical lung lesion with irregular borders. Laboratory evaluations were negative for rickettsiae, Coxiella burnetii, HIV, Plasmodium spp., and Mycobacterium tuberculosis. Four days after admission, gram-negative coccobacilli grew from his blood culture. Brucella IgM titer was 1:1,920. The patient received appropriate treatment for 6 weeks (Table) and recovered. Brucella IgM titers dropped to 1:40. Four months later, he returned to the infectious diseases clinic exhibiting fever, chills, and clinical and sonographic evidence of epididymo-orchitis. Brucella IgM titers rose to $1: 1,240$. Treatment was resumed for 3 months. In addition, a thoracoscopic biopsy of the lung lesion was performed to rule out malignancy. Pathologic examination of the biopsy specimen revealed a focus of fibrosis, with giant cells surrounded by lymphocytes (online Technical Appendix Figure, http://wwwnc.cdc.gov/EID/article/22/4/15-1192Techapp1.pdf). After treatment, the patient's symptoms resolved and titers returned to low levels.

The long symptom-to-diagnosis interval (range 2197 days) for patients in this report is alarming (Table). Treatment delays are associated with increased focal complications and relapse rates (3). Further, high casefatality rates, allegedly due to low physician awareness, were reported in a largely immigrant cohort of brucellosis patients in Germany (4).

Several circumstances might have led to the failure to include brucellosis in the initial differential diagnosis for these patients, even in a disease-endemic region. First, we can assume that physicians are unfamiliar with the ceremonial slaughter central to the celebrations of Ethiopian Jews. 
Table. Characteristics, treatment, and outcomes of patients with brucellosis who engaged in ritual slaughter, Israel ${ }^{*}$

\begin{tabular}{|c|c|c|c|c|c|c|c|c|}
\hline $\begin{array}{l}\text { Pt } \\
\text { no. }\end{array}$ & $\begin{array}{l}\text { Age, } \\
\text { y/sex }\end{array}$ & $\begin{array}{l}\text { Clinical } \\
\text { features }\end{array}$ & $\begin{array}{l}\text { Laboratory } \\
\text { findings at } \\
\text { admission }\end{array}$ & Chest imaging & $\begin{array}{l}\text { Alternative } \\
\text { diagnoses }\end{array}$ & $\begin{array}{l}\text { Fever-to- } \\
\text { diagnosis } \\
\text { interval, d }\end{array}$ & Complication & $\begin{array}{c}\text { Treatment and } \\
\text { outcome }\end{array}$ \\
\hline 1 & $68 / \mathrm{M}$ & $\begin{array}{c}\text { Cervical neck } \\
\text { pain; cough; } \\
\text { night sweats; } \\
38^{\circ} \mathrm{C}\end{array}$ & $\begin{array}{c}\mathrm{Hb}, 11.9 \mathrm{mg} / \mathrm{dL} ; \\
\text { leukocytes, } 16.3 \times \\
10^{3} / \mu \mathrm{L} ; \mathrm{AST}, 63 \\
\mathrm{U} / \mathrm{L} ; \mathrm{ALT}, 118 \mathrm{U} / \mathrm{L}\end{array}$ & $\begin{array}{c}\text { CT: apical lung } \\
\text { finding, new onset }\end{array}$ & $\begin{array}{c}\text { Asthma } \\
\text { exacerbation; } \\
\text { lung } \\
\text { malignancy }\end{array}$ & 21 & $\begin{array}{c}\text { Focal lung } \\
\text { lesion; relapse: } \\
\text { epididymo- } \\
\text { orchitis; } \\
\text { suspected } \\
\text { osteomyelitis C6: } \\
\text { increased uptake } \\
\text { bone scan }\end{array}$ & $\begin{array}{l}\text { STR/2 wk, dox } \\
\text { + cipro/6 wk; } \\
\text { relapse: rising } \\
\text { Brucella titers + } \\
\text { epididymitis; } \\
\text { same } 3 \\
\text { drugs/12 wk; } \\
\text { recovery }\end{array}$ \\
\hline \multirow[t]{2}{*}{2} & $70 / \mathrm{M}$ & $\begin{array}{c}\text { 1st } \\
\text { admission: } \\
\text { fever; } \\
\text { productive } \\
\text { cough }\end{array}$ & $\begin{array}{c}\mathrm{Hb}, 14.9 \mathrm{mg} / \mathrm{dL} ; \\
\text { leukocytes, } 12 \mathrm{x} \\
10^{3} \text { cells/} / \mu \mathrm{L} ; \\
\text { platelets, } 136 \mathrm{x} \\
10^{3} / \mu \mathrm{L} ; \mathrm{AST}, 61 \\
\mathrm{U} / \mathrm{L} ; \mathrm{ALT}, 47 \mathrm{U} / \mathrm{L}\end{array}$ & $\begin{array}{l}\text { Chest radiograph: } \\
\text { retrocardial } \\
\text { infiltrate }\end{array}$ & $\begin{array}{c}\text { Asthma } \\
\text { exacerbation; } \\
\text { bronchitis }\end{array}$ & NA & & $\begin{array}{l}\text { Inhalatants: IV } \\
\text { solumedrol, } \\
\text { then oral } \\
\text { prednisone }\end{array}$ \\
\hline & & $\begin{array}{c}\text { 2nd } \\
\text { admission: } \\
\text { hypothermia: } \\
35.7^{\circ} \mathrm{C} \text {; pulse } \\
\text { oximetry, } \\
94 \% \text { on room } \\
\text { air }\end{array}$ & $\begin{array}{c}\mathrm{Hb}: 12 \mathrm{mg} / \mathrm{dL} ; \\
\text { leukocytes, } 2.8 \mathrm{x} \\
10^{3} \text { cells/ } \mu \mathrm{L}, 3.7 \times \\
10^{3} \text { cells/ } \mu \mathrm{L} ; \\
\text { platelets, } 38 \mathrm{x} \\
10^{3} / \mu \mathrm{L} ; \mathrm{Na}, 129 \\
\mathrm{meq} / \mathrm{L} ; \mathrm{AST}, 134 \\
\mathrm{U} / \mathrm{L} ; \mathrm{ALT}, 100 \mathrm{U} / \mathrm{L}\end{array}$ & $\begin{array}{l}\text { CT: multiple RUL } \\
\text { pulmonary } \\
\text { nodules; } \\
\text { mediastinal } \\
\text { lymphadenopathy }\end{array}$ & TB & 92 & Sepsis & $\begin{array}{l}\mathrm{STR} / 2 \mathrm{wk} \text {, } \\
\text { dox/6 wk: } \\
\text { recovery }\end{array}$ \\
\hline 3 & $45 / \mathrm{M}$ & $\begin{array}{c}\text { Fever; } \\
\text { prolonged } \\
\text { headache }\end{array}$ & $\begin{array}{c}\mathrm{Hb}, 11.7 \mathrm{mg} / \mathrm{dL} ; \\
\mathrm{AST}, 58 \mathrm{U} / \mathrm{L} ; \mathrm{ALT} \\
102 \mathrm{U} / \mathrm{L} ; \mathrm{Na}, 133 \\
\mathrm{meq} / \mathrm{L} ; \mathrm{ESR}, 70 \\
\mathrm{~mm} \mathrm{Hg} / \mathrm{h}\end{array}$ & $\begin{array}{l}\text { Chest radiograph: } \\
\text { diffuse bilateral } \\
\text { pulmonary } \\
\text { nodules rule out } \\
\text { miliary TB }\end{array}$ & $\begin{array}{c}\text { TB; } \\
\text { cryptococcal } \\
\text { meningitis }\end{array}$ & 21 & $\begin{array}{c}\text { Suspected } \\
\text { discitis C5-6 per } \\
\text { MRI }\end{array}$ & $\begin{array}{c}\text { Genta/wk, dox + } \\
\text { cotrim/12 wk; } \\
\text { recovery }\end{array}$ \\
\hline 4 & $55 / \mathrm{M}$ & $\begin{array}{l}\text { Cough; fever; } \\
\text { low back } \\
\text { pain }\end{array}$ & $\begin{array}{c}\mathrm{Hb}, 11.8 \mathrm{mg} / \mathrm{dL} ; \\
\mathrm{AST}, 86 \mathrm{U} / \mathrm{L} ; \mathrm{ALT} \\
120 \mathrm{U} / \mathrm{L} ; \mathrm{ESR}, 90 \\
\mathrm{~mm} \mathrm{Hg} / \mathrm{h} ; \mathrm{CRP} \\
92.6 \mathrm{mg} / \mathrm{L}\end{array}$ & $\begin{array}{l}\text { Chest radiograph: } \\
\text { peribronchial } \\
\text { thickening }\end{array}$ & $\begin{array}{l}\text { Pneumonia (rx } \\
\text { cefuroxime); } \\
\text { temporal } \\
\text { arteritis }\end{array}$ & 28 & & $\begin{array}{l}\text { Genta/2 wk, } \\
\text { dox/6 wk; } \\
\text { persistent low } \\
\text { back pain }\end{array}$ \\
\hline 5 & $49 / F$ & Cough; fever & $\begin{array}{c}\mathrm{Hb}, 9.5 \mathrm{mg} / \mathrm{dL} ; \\
\text { leukocytes, } 3.7 \times \\
10^{3} \text { cells } / \mu \mathrm{L} ; \\
\text { platelets, } 116 \mathrm{x} \\
10^{3} / \mu \mathrm{L}\end{array}$ & $\begin{array}{l}\text { Chest radiograph: } \\
\text { no pathologic } \\
\text { changes; CT: no } \\
\text { pathologic } \\
\text { changes }\end{array}$ & $\begin{array}{l}\text { TB; infective } \\
\text { endocarditis } \\
\text { caused by } \\
\text { Actinobacillus } \\
\text { ureae }\end{array}$ & 90 & & $\begin{array}{c}\text { Genta/2 wk; dox } \\
\text { + rif/7 wk; } \\
\text { recovery }\end{array}$ \\
\hline
\end{tabular}

The tradition includes slaughtering, skinning, and eviscerating a sheep, followed by mincing of the sheep meat. This venerated ritual is performed by trained members of the Ethiopian community and supervised by the spiritual leader, the Kes (5). Second, patients were consistently reluctant to disclose their participation in ceremonial slaughter to medical staff. Third, the managing physicians considered differential diagnoses for febrile respiratory illness in line with the patients' Ethiopian origins: reactivation of TB or chronic pulmonary disease exacerbation (6). Patients 3 and 5 had a history of prolonged cough at admission; patient 3 had chest radiograph results suggestive of miliary TB. Finally, for patient 5, Actinobacillus ureae was initially but erroneously identified as the cause of bacteremia.

All patients in our study had clinical or radiologic evidence of lung involvement. Causality between exposure to Brucella-infected aerosols and pulmonary manifestations of brucellosis has been demonstrated in animal models. After an aerosol challenge with $B$. melitensis, animal lungs have shown perivascular inflammation as well as microgranulomas (7). In a study of hunters infected with B. suis, in which $38 \%$ had respiratory symptoms, aerosol spread or conjuctival innoculation was considered the most likely route of infection (3).

Aerosol exposure during slaughter could be linked to the pulmonary manifestations of brucellosis observed in these patients. The granulomatous changes in the lung biopsy specimens of patient 1 are typical of lung involvement in brucellosis $(8)$. The patients in this report did not use protective gear during contact with animal parts, which inevitably increased their risk for infection through direct or aerosol contact (9).

This reports illustrates an unsuspected mode of brucellosis transmission in an area with soaring brucellosis 
rates: transmission from infected animals to persons clandestinely engaging in ritual slaughter; specifically, an Ethiopian Jewish community. Physicians in countries receiving immigrants should be aware of ceremonial practices that place patients at risk for zoonoses. The severe respiratory manifestations that ensued following aerosol exposure to animal blood or secretions suggest that brucellosis with pulmonary involvement after inhalation of Brucella-infected aerosols might be more common than previously documented.

\section{References}

1. Shemesh A, Yagupsky P. Increasing incidence of human brucellosis in southern Israel after the cessation of a veterinarian control campaign. Air Water Borne Diseases. 2013;2:112. http://www.omicsgroup.org/journals/increasing-incidence-ofhuman-brucellosis-in-southern-israel-after-the-cessation-ofa-veterinarian-control-campaign-2167-7719.1000112. php?aid $=17444$

2. Brucellosis-Israel (02): (Hadarom) melitensis, bovine, human. ProMED-mail. 201531 Oct [cited 2015 Oct 31]. http://www.promedmail.org, archive no. 20151031.3757610.

3. Eales KM, Norton RE, Ketheesan N. Short report: brucellosis in northern Australia. Am J Trop Med Hyg. 2010;83:876-8. http://dx.doi.org/10.4269/ajtmh.2010.10-0237

4. Al Dahouk S, Neubauer H, Hensel A, Sconeberg I, Nockler K, Alpers K, et al. Changing epidemiology of human brucellosis, Germany 1962-2005. Emerg Infect Dis. 2007;13:1895-900. http://dx.doi.org/10.3201/eid1312.070527

5. Salomon H. Blood between the Beta Israel and their Christian neighbours in Ethiopia - key symbols in an inter-group context [article in Hebrew]. Jerusalem Studies in Jewish Folklore. Mandel Institute for Jewish Studies. 1993 [cited 2015 Jan 6]. http://www.jstor.org/stable/23356293

6. Rosenberg R, Vinker S, Zakut H, Kizner F, Nakar S, Kitai E. An unusually high prevalence of asthma in Ethiopian immigrants to Israel. Fam Med. 1999;31:276-9.

7. Henning LN, Miller SM, Pak DH, Lindsay A, Fisher DA, Barnewall R, et al. Pathophysiology of the rhesus macaque model for inhalational brucellosis. Infect Immun. 2012;80:298-310. http://dx.doi.org/ 10.1128/IAI.05878-11

8. Theegarten D, Albrecht S, Totsch M, Teschler H, Neubauer H, Al Dahouk S. Brucellosis of the lung: case report and review of the literature. Virchows Arch. 2008;452:97-101. http://dx.doi.org/ 10.1007/s00428-007-0518-0

9. Nabukenya I, Kaddu-Mulindwa D, Nasinyama G. Survey of Brucella infection and malaria among abattoir workers in Kampala and Mbarara districts, Uganda. BMC Public Health. 2013;13:901. http://dx.doi.org/10.1186/1471-2458-13-901

Address for correspondence: Inbal Fuchs, Clalit Health ServicesInfectious Diseases, 17 Shlomo Hamelech, Beer Sheva 85545, Israel; email: fuksen@bgu.ac.il,inbalfp@gmail.com

\section{Follow-up of Ebola Patient, 2014-2015}

\section{Venkatesh Srinivas, Pragya Yadav, Veena Mittal, Gouri Chaubal, Mala Chhabra, Sanjay Mattoo, Arvind Rai, Devendra T. Mourya}

Author affiliations: National Centre for Disease Control, New Delhi, India (S. Venkatesh, V. Mittal, M. Chhabra, A. Rai); National Institute of Virology, Pune, India (P. Yadav, G. Chaubal, D.T. Mourya); Airport Authority of India, New Delhi (S. Matto)

DOI: http://dx.doi.org/10.3201/eid2204.151405

To the Editor: The 2014-2015 epidemic of Ebola virus disease (EVD) in West Africa affected 23,666 persons and caused 14,603 deaths (1). The World Health Organization (WHO) declared the epidemic a public health emergency (2). Although Ebola virus is transmitted by unprotected physical contact with infected persons, published reports about which body fluids are infected or the risk for fomite transmission are few (3). For most cases, virus was detected by reverse transcription PCR (RT-PCR) of clinical (saliva, feces, semen, breast milk, tears, nasal blood, skin swab) and environmental specimens (4). Earlier reports of the followup of recovered patients stated that viral RNA was detected by RT-PCR for up to 33 days in vaginal, rectal, and conjunctival swab samples from 1 patient and up to 101 days in seminal fluid from 4 patients. Infectious virus was detected in 1 seminal fluid sample 82 days after disease onset $(4,5)$.

Attendees at the Eighth Meeting of the WHO Advisory Group on the EVD Response (1) discussed potential risk factors, including hidden chains of transmission and sexual transmission, and determined the following criteria. A country can declare "interruption of transmission" when 42 days have elapsed since the last diagnosis of a case. A country can declare that the "outbreak has stopped" when test results from the last case are negative twice or after another 90-day interval. For determining a cutoff for finally declaring the strategy and criteria for elimination, extensive follow-up on infectivity of semen in Ebola survivors is needed.

We report follow-up of a man who recovered from EVD and was monitored for 165 days after he was declared Ebola-free. The 26-year-old man from India returned to New Delhi, India, from Liberia on November 10, 2014, with a certificate from the government of Liberia stating that he was "cured" of Ebola. Because EVD is considered an exotic disease in India, he was placed in isolation at the Airport Health Organization quarantine center at Indira Gandhi International Airport, New Delhi (6). Serum and semen samples were collected and sent to the National Centre for Disease Control (NCDC), New Delhi, and the National Institute of Virology (NIV), Pune, India. The serum was negative by 